\title{
Az akut traumás vérzés és véralvadási zavar korszerü ellátása
}

\author{
Szentkereszty Zoltán dr. \\ Debreceni Egyetem Kenézy Gyula Egyetemi Kórház, Központi Aneszteziológiai és Intenzív Terápiás Osztály, \\ Debrecen
}

\begin{abstract}
A súlyos trauma/politraumatizáció a halálozás gyakori oka, a fiatal korosztályban pedig a vezető halálozási ok. A korai halálozásért gyakran a kivérzés felelős. Ennek hátterében a vérzés megindulását követően, sokszor már korán kialakuló, a vérzést tovább fokozó traumás véralvadási zavar (TIC: trauma-induced coagulopathy) áll. Másrészről a vérzéses traumás sokk ellátásakor alkalmazott, nagy mennyiségü vérkészítmény, a masszív transzfúzió súlyos - akár halálos - szövődményekhez vezethet. A masszív traumás vérzés korszerű szemléletű, agresszív ellátása mind a kivérzés és halálozás, mind a késői szövődmények elkerülésében hatékony. Emellett e szemlélet szervesen illeszkedik a vérgazdálkodási koncepcióhoz. Az összefoglaló közlemény az akut trauma ellátásán belül a traumás vérzés, illetve a traumás véralvadási zavar korszerű, célirányos, preventív szemléletû ellátásával foglalkozik, a hangsúlyt az elvi háttérre helyezve. Célja, hogy az ilyen irányú ellátásban közvetlenül részt nem vevők is átlássák e tevékenység lényegét. Orv Hetil. 2020; 161(37): 1599-1605.
\end{abstract}

Kulcsszavak: politraumatizáció, kivérzés, traumás véralvadási zavar, célirányos ellátás, PBM

\section{Up-to-date management of acute traumatic bleeding and coagulopathy}

\begin{abstract}
Major trauma is a frequent cause of death, and is the leading cause of death in the younger agegroups. Severe bleeding is often responsible for early mortality. The background of the latter is the trauma-induced coagulopathy (TIC), which - often very early - develops after the onset of bleeding. The high amount of blood products, i.e., massive transfusion administered during the management of traumatic bleeding can result in severe, even fatal complications. Modern, aggressive management of masssive traumatic bleeding is effective in reducing exsanguination and mortality or late complications. This method also fits into the concept of Patient Blood Management. This review deals with the up-to-date, goal-directed, preventive management of traumatic bleeding and coagulopathy, with emphasis on theoretical grounds. The aim is to present the essence of this management method also to those who are not directly involved in this activity.
\end{abstract}

Keywords: major trauma, severe bleeding, trauma-induced coagulopathy, goal-directed management, PBM

Szentkereszty Z. [Up-to-date management of acute traumatic bleeding and coagulopathy]. Orv Hetil. 2020; 161(37): 1599-1605.

(Beérkezett: 2020. május 4.; elfogadva: 2020. június 4.)

\section{Rövidítések}

APTI = aktivált parciális tromboplasztinidő; $\mathrm{CT}=$ (clotting time) véralvadási idő; EXTEM = az extrinszik alvadási mechanizmus vizsgálatára szolgáló viszkoelasztikus, betegágy melletti teszt; FC = faktorkoncentrátum; FFP = friss fagyasztott plazma; FIBTEM = a fibrinogénszint vizsgálatára szolgáló viszkoelasztikus, betegágy melletti teszt; FVII = a VII-es alvadási faktor; FXIII = a XIII-as alvadási faktor; GDCT $=$ (goal-directed coagulation treatment) célirányos alvadáskezelés; $\mathrm{Hb}=$ he- moglobin; INR = (international normalized ratio) nemzetközi normalizált ráta; $\mathrm{MTP}=$ masszív transzfúziós protokoll; PBM = (Patient Blood Management $)$ hazai adaptációja a Nemzeti Véradó és Vérmentő Program; PCC $=$ protrombinkomplexkoncentrátum; POCT $=$ (point-of-care test $)$ mútőasztal/betegágy melletti teszt; $\mathrm{PT}=$ protrombinidő; rFVIIa = a VII-es számú rekombináns aktivált alvadási faktor; ROTEM = (rotational thromboelastometry) rotációs tromboelasztometria; SCT = standard koagulációs teszt; TASH = (trauma-associated severe haemorrhage) traumához kapcsolódó súlyos vérzés; TI = 
trombinidö; TIC = (trauma-induced coagulopathy) trauma indukálta coagulopathia; VET = viszkoelasztikus teszt; VVS = vörösvérsejt

A traumás esetek kb. 30\%-a súlyos trauma/politraumatizáció, amely tízből egy halál oka, a 45 év alattiaknál pedig a vezető halálozási ok. A potenciálisan megelőzhető korai halálozásért az esetek 20\%-ában a kivérzés felelős, másrészt a kontrollál(hatat)atlan traumás vérzés letalitása $55 \%[1]$. Ennek hátterében a vérzés megindulását követően - a súlyos sérültek közel 30\%-ában már korán - kialakuló, a vérzést tovább fokozó traumás véralvadási zavar áll. A TIC egy, az elmúlt évtizedek alatt felismert, de a mai napig nem teljesen megértett multifaktoriális primer állapot $[2,3]$, amelynek kialakulásában a vérzéses sokk, a glycocalixdisruptio és endothelsérülés, a szöveti hypoperfusio és a társuló acidosis, a szövetkárosodás miatti trombomodulin-upreguláció, trombin-trombomodulin komplex generáció, végeredményben az antikoaguláns és a fibrinolyticus utak egyidejü aktiválódása játszik szerepet. Központi jelentőségű az alacsony fibrinogénszint. Az előbbiek mellett a hypothermia, az alvadási faktorok felhasználása és hígulása is fontos kóroki tényező. A kép súlyosságát számos egyéb tényező befolyásolhatja, ezek az életkor, a genetikai konstitúció, a társbetegségek, a gyulladásos folyamatok, a krónikus gyógyszerszedés, illetve a társuló agysérülés és a folyadékresuscitatio módja lehetnek. A TIC jelenléte bizonyítottan magasabb morbiditással és letalitással jár [4]. Kiemelt szerepe van a sebészileg el nem látható szivárgó, szöveti vagy kiserekből eredő vérzés fenntartásában, illetve súlyosbodásában. A vérzés időben történő kontrollja kevesebb VVS-transzfúzió adásával társul.

A véralvadási zavar a német traumaregiszter adatai alapján a súlyos sérültek egyharmadában már a kórházi felvételkor kimutatható [5], a késóbbiekben pedig kialakulásának valószínûsége tovább nő.

\section{Diagnosztika}

Az időfaktor figyelembevételével nyilvánvaló, hogy a legelőnyösebb a TIC megelőzése, illetve minél előbb történő korrekciója. Ennek feltétele az alvadási zavar korai felismerése, diagnózisa, sốt a klinikai kép, a sérülés jellege, súlyossága alapján annak anticipációja. A diagnosztika hagyományos laboratóriumi vizsgálatokkal (SCT) vagy viszkoelasztikus tesztekkel (VET-ek) történhet. A kezdeti tesztek után azok vagy más tesztek észszerú ismétlése javasolt az állapot, illetve a kezelés hatékonyságának követésére.

SCT: APTI, PT/INR, TI, fibrinogénszint, thrombocytaszám. Ezekről ismert, hogy időigényesek, statikusak, és mivel csak a faktorok szintjét mérik, nem tükrözik a valós alvadási folyamatokat. SCT-vel kezdetben csak empirikus alvadáskezelés kezdhető, vagy a célirányos kezelés csak késéssel (30-60 perc) indulhat.

Nem rendezhetó coagulopathia esetén javasolt a FXIII-szint ellenőrzése is, bár egyesek akár rutinszerú vizsgálatát javasolják. Szükség lehet a thrombocytafunkció vizsgálatára is.

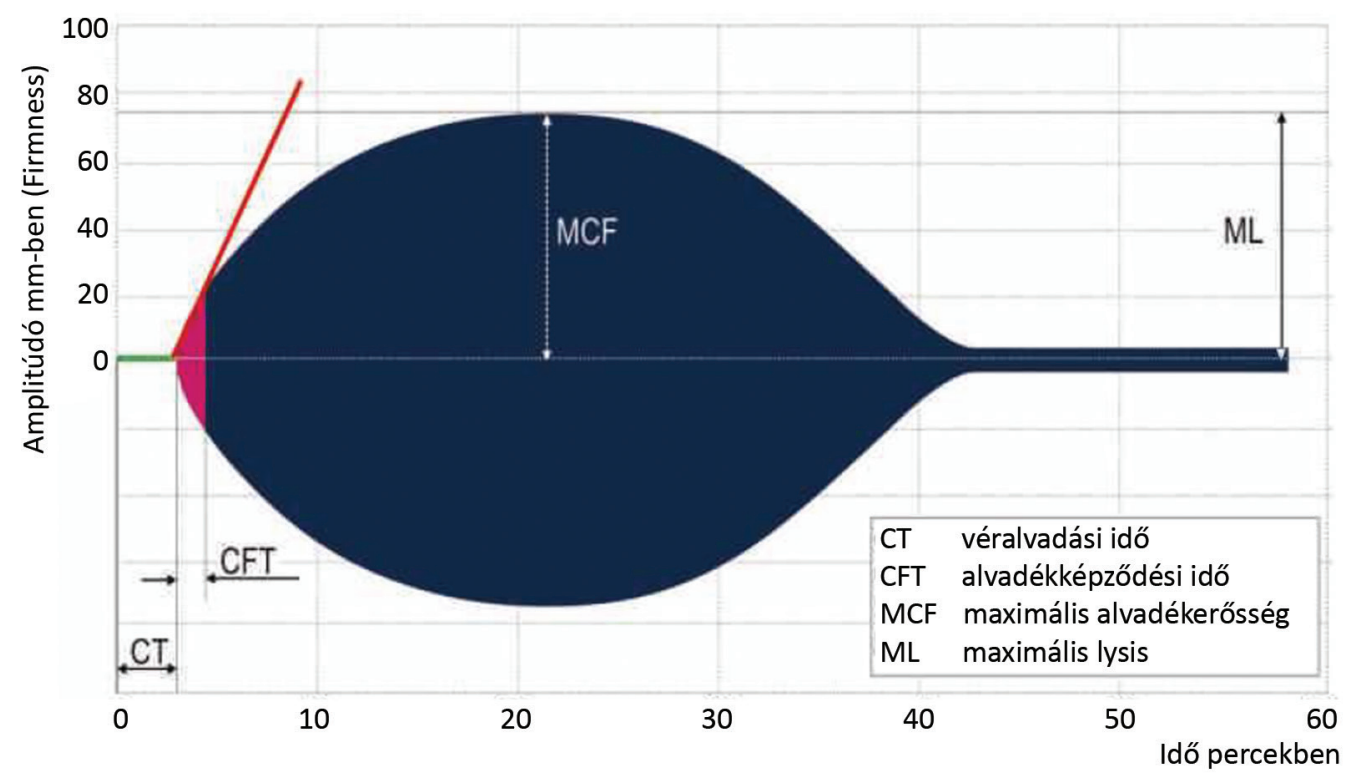

\begin{tabular}{l|l} 
1. ábra $\quad$ A viszkoelasztikus teszt értelmezése
\end{tabular}

A vizsgálat során nyert görbe az alvadékképződés és a lysis folyamatát írja le az idő függvényében. Mutatja a koaguláció megindulásáig (CT) és a 20 mm-es amplitúdó kialakulásáig (CFT) eltelt időt, az elért maximális alvadékamplitúdót (MCF) és a lysis következtében elért maximális amplitúdócsökkenést a vizsgálat befejezéséig (ML)

$\mathrm{CT}=$ véralvadási idő; $\mathrm{CFT}=$ alvadékképződési idő; $\mathrm{MCF}=$ maximális alvadékerősség; $\mathrm{ML}=$ maximális lysis 
VET: A kórházi ellátás során a „betegágy” mellett is végezhető (POCT). A mérés időtartamának csökkentése, illetve az alvadás egyes részfolyamatainak szeparált vizsgálhatósága céljából különböző aktiváló vagy gátló anyagokat adagolnak a teljes vérhez. Már néhány percen belül hozzájuthatunk kezdeti információhoz. A TIC tekintetében különösen fontos a CT (a viszkoelasztikus haemostaticus tesztben a mozgó komponens kitérésének kezdetéig, vagyis a koaguláció kezdetéig eltelt idő), az EXTEM (az extrinszik alvadási mechanizmus vizsgálata) és a FIBTEM (a véralvadék kialakulásának és stabilitásának vizsgálata, a fibrinogén mennyiségére és a fibrinpolimerizációra utal). Az alvadási zavarról kapott részletes és differenciált eredmények alapján [6] korán elkezdhető a célirányos kezelés. A módszerhez ellátási algoritmusok kapcsolhatók. A VET-ek alapvető típusa a viszkoelasztometria és a viszkoelasztográfia. Hazánkban az előbbi, ROTEM $^{\circledR}$-vizsgálat (1. ábra) terjedt el. Az újabb generációs készülék használata egyszerüsödött, mindössze egy kémcsőnyi vér beadása szükséges. A vizsgálatok nem olcsók, de jó gyakorlattal költségük a kimenetel javulásával és az indirekt költségek csökkenésével bőven megtérülhet.

Az aktuális irányelvek - például az európai [7] - nem teszik VET alkalmazását kizárólagossá, már csak azért sem, mert egyelőre nem elég széleskörüen hozzáférhetők.

\section{Ellátás}

A masszív traumás vérzés ellátásának két alapvető összetevője a VVS-transzfúzió és az alvadási zavar kezelése.

A VVS-transzfúzió során a megszorító gyakorlat követendő, a Hb célértéke 70-90 g/l. A vörösvérsejtek a megfelelő oxigénszállítási kapacitás tényezői, részt vesznek az értónus és a mikrocirkuláció szabályozásában, ily módon meghatározói a szöveti oxigénigény biztosításának. A véralvadásban szintén szerepük van: reológiai hatáson keresztül befolyásolják a thrombocytamarginációt, másrészt elősegítik a trombingenerációt. Számos tanulmány alapján az előbbi fontos funkciók ellenére biztonságosnak, sốt sok tekintetben (például halálozás, akut tüdősérülés, infekció, veseelégtelenség) előnyösebbnek tünik a megszorító stratégia. Igaz ez a magas cardiovascularis rizikójú sérültekre és agysérültekre is. További megszorító lehetőség a permisszív hypotensio (más néven késleltetett resuscitatio) koncepciója [8]: a VVStranszfúzió késleltetése a masszív vérzés sebészi ellátásáig (nem alkalmazható az előbbi kockázati csoportokban). A megszorító szemlélet egyértelműen kevesebb VVS-felhasználást eredményez. Az alacsony felvételi $\mathrm{Hb}$-szint egyébként jelentős vérzésre utal, míg a normális érték nem zárja ki a vérzést, ezért a Hb-szintet az ellátás során (többször) ellenőrizni kell.

A TIC rendezése során mindenképpen szükségessé válik az elégtelen mennyiségű alvadási faktorok valamilyen módon történő pótlása. Az alvadási kaszkád egyes ele- meinek kezdeti, empirikus pótlását, annak sorrendjét azok élettani készlete, termelésének és felhasználódásának dinamikája határozza meg. Ebben irányt mutatnak az aktuális hazai [9] és nemzetközi irányelvek és különböző hozzáférhetô ellátási algoritmusok, leporellók (2. ábra). A pótlás ideálisan koagulációs tesztek eredményei alapján folytatódik, ez a célirányos alvadáskezelés (GDCT) $[10,11]$.

A gyógyszeres beavatkozások előtt vagy közben meg kell, hogy történjen a sebészi vérzéskontroll. Természetesen biztosítani kell a véralvadáshoz az optimális homeostaticus környezetet: testhőmérséklet $>34{ }^{\circ} \mathrm{C}$, pH>7,2 és $\mathrm{Ca}^{++}>1$ mmol/1 [12]. Az előbbiek mellett súlyos trauma (ISS>16) és/vagy sokk esetén - a feltételezhető fibrinolysis gátlására javasolt 3 órán belül megkezdve, többféle adagolási sémával, összesen $2 \mathrm{~g}$ tranexámsav adása [13]. Szükséges még az elégséges természetesen múködő - thrombocytaszám (>50 000/ $\mu \mathrm{l}$, agysérülés esetén $>100000 / \mu \mathrm{l})$ is [14].

A hiányzó/pótlandó faktorok közül kiemelkedő jelentôségú a fibrinogén. Mint az alvadékképződés központi anyaga és a thrombocytaaggregáció ligandja, felhasználódása vérzés során elkerülhetetlen $[15,16]$. A szervezetben a keringő mennyiségen (kb. $10 \mathrm{~g}$ ) felül nincs raktározott tartalék, szintje a vérzéssel párhuzamosan gyorsan esik. A sérültek kórházi felvételekor észlelt 100 g/dl alatti Hb-szint 73\%-ban, míg a 6-nál magasabb bázishiány $63 \%$-ban társult 1,5 g/l alatti fibrinogénszinttel, hypotensio pedig 41\%-ban járt alacsony fibrinogénszinttel [17]. A felvételi hypofibrinogenaemia a masszív transzfúzió [18], illetve a halálozás prediktora [19]. Időben történő pótlása alapfeltétele a vérzés megállításának [20]. A cél az 1,5-2 g/l szintnek vagy az ennek megfelelő funkcionális aktivitásnak (például FIBTEM alapján) a fenntartása.

Fontos szerepe van a prokoaguláns faktoroknak (II., VII., IX., X.) az alvadási folyamat trombingenerációs fázisában. A cél az APTI és/vagy a TI 1,5-szeres megnyúlás alatt tartása, illetve megfelelő CT az EXTEM-teszten. A FXIII (korábban fibrinstabilizáló faktor) trombin által aktiválódva a fibrinkeresztkötések kialakulását serkenti, az alvadék stabilitását biztosítja.

Az alvadási faktorok pótlása FFP-vel és faktorkoncentrátumokkal (FC), illetve ezek kombinálásával is történhet.

FFP-alapú pótlás: A FFP természetes egyensúlyban tartalmazza az összes koagulációs (és antikoagulációs) faktorokat, így fibrinogént is (kb. 0,2-0,6 g $200 \mathrm{ml}$-es egységenként). Számos hátránya ismert: a vércsoportegyezés igénye, a beadási késedelem (beszerzés, kiolvasztás), a FFP faktortartalma erősen változó és aktuálisan nem ismert, a citráttartalom, a megfelelő pótlás volumenterheléssel járhat, önhígítás az érpályán belül, fertőzésátvitel, valamint a transzfúziós szövődmények lehetősége [21]. A FFP gyakran fix arányú transzfúziós protokoll része, masszív vérzés esetén, elsősorban a kezdeti empirikus fázisban - helyenként eltérően - legalább 
A trauma indukálta coagulopathia kezelésének algoritmusa

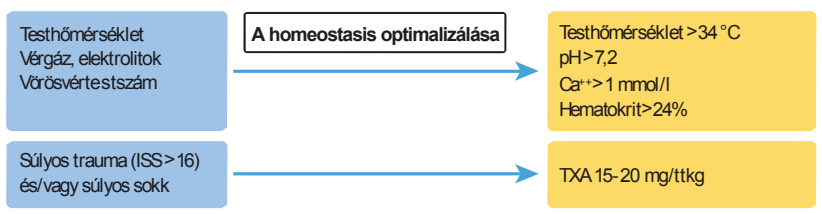

ROTEM (EXTEM, INTEM, FIBTEM, APTEM)-vizsgálat

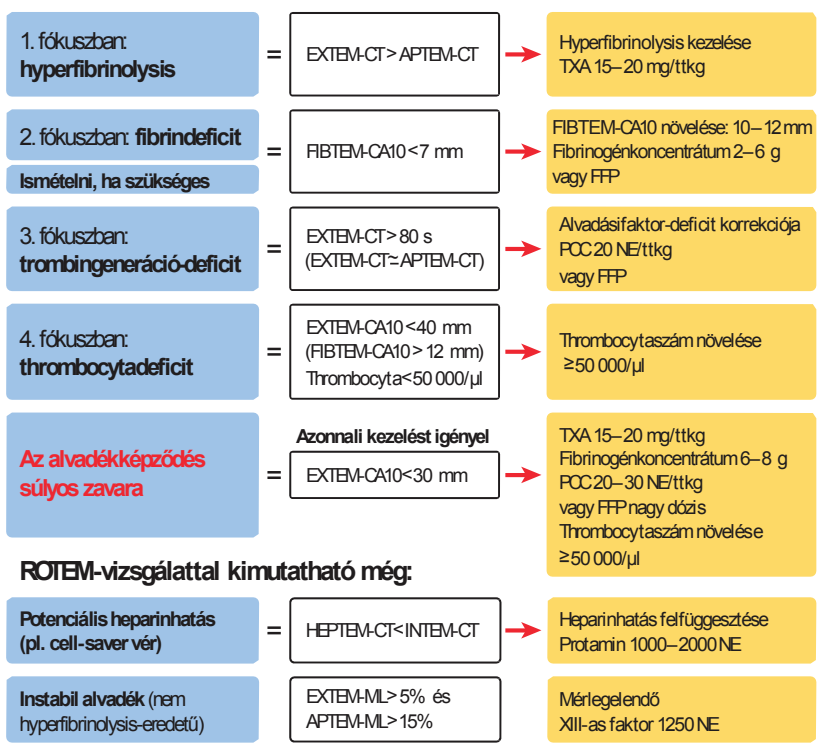

APIEM-ML $>15 \%$
XII-as faktor 1250NE

\section{A trauma indukálta coagulopathia kezelésének algoritmusa}
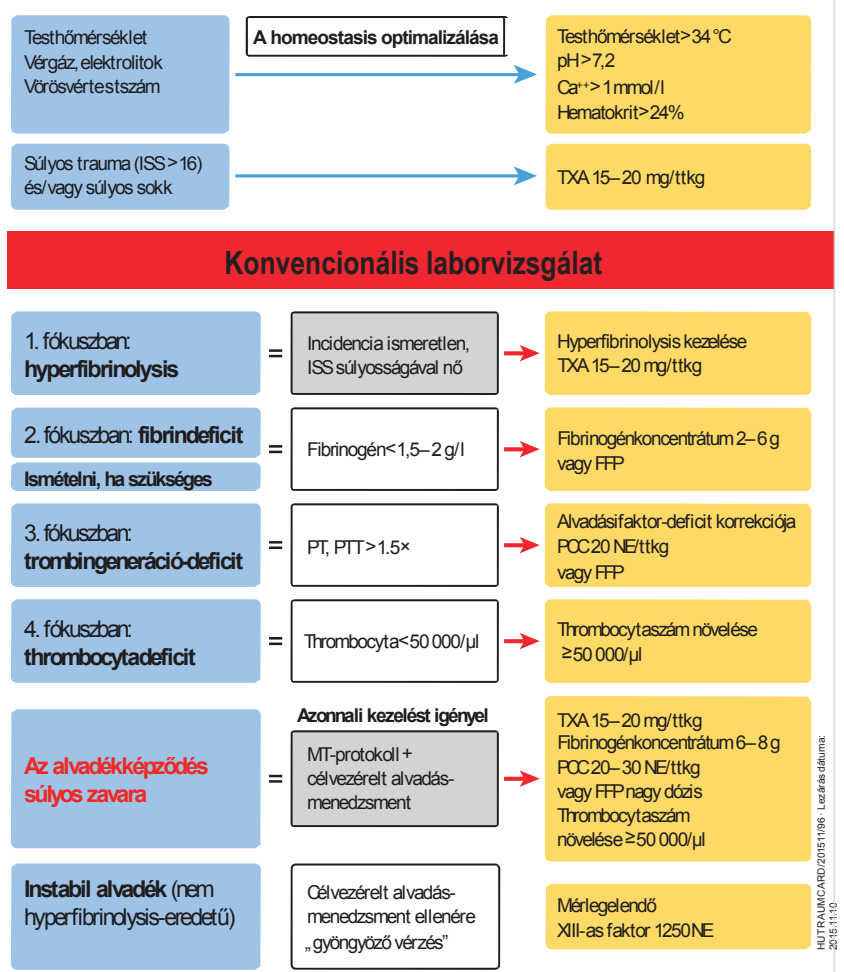

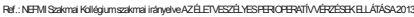

\section{CSL Behring}

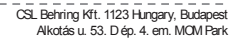

2. ábra

\begin{abstract}
Normális ROTEM-görbék
Célirányos ellátási algoritmus. Magyar nyelvre lefordított leporelló

APTEM = a véralvadék kialakulásának aktiválása aprotinin hozzáadásával; $\mathrm{CA}=$ vérrög amplitúdója $; \mathrm{CT}=$ véralvadási idő; $\mathrm{EXTEM} \mathrm{=} \mathrm{az} \mathrm{extrinszik}$ alvadási mechanizmus vizsgálatára szolgáló viszkoelasztikus, betegágy melletti teszt; FFP = friss fagyasztott plazma; FIBTEM = a fibrinogénszint vizsgálatára szolgáló viszkoelasztikus, betegágy melletti teszt; HEPTEM = heparinhatás kimutatására szolgáló viszkoelasztikus, betegágy melletti teszt; ISS = a sérülés súlyosságának pontozási rendszere; $\mathrm{MCF}=$ maximális alvadékerősség; $\mathrm{ML}=$ maximális lysis; $\mathrm{MT}=$ masszív transzfúzió; $\mathrm{PCC}=$ protrombinkomplex-koncentrátum; PPT = prandialis premix terápia; PT = protrombinidő; ROTEM = tromboelasztometria; TXA = tranexámsav
\end{abstract}

minden beadott 2 VVS-egységhez, de ideálisan minden egységhez 1-1 egység FFP-t és 'poolozott' thrombocytát adnak (1:1:2-1:1:1 arány) [22, 23]. Az európai irányelv fibrinogénpótlásra nem javasolja a pótlás késedelmessége és a bizonytalan hatékonyság miatt. A vérkészítmények előkészítésének és hozzáférhetőségének gyorsítása céljából - elsősorban az Egyesült Államokban - népszerü előre meghatározott sorrendü, tartalmú, mennyiségú és arányú, esetenként faktorkészítménnyel kiegészített vérkészítménycsomagok előkészítése, majd gyors kiadása a vérbankból, ez a „klasszikus” masszív transzfúziós protokoll (MTP).

Faktorkoncentrátum-alapú pótlás: A FC-ok általános előnye a kis volumenben lévő ismert, magas, standardizált hatóanyag-tartalom, illetve az azonnali hozzáférhetőség és beadhatóság. Legfőbb hátrányuk a magas ár, költséghatékonyságukat azonban már többször bizonyították [24].

Elsőként a fibrinogén pótlása jön szóba. Ez masszív vérzés jelei vagy gyanúja esetén azonnal - rutinszerüen
- megkezdendő, így az állapot mélyülése megelőzhető. A kezdő - általában még „vakon” becsült - adagra eltérő ajánlások vannak: többnyire 2-6 g beadását javasolják, mások 2 g adását 4 E VVS-transzfúziónként. A későbbiekben a TIC laboratóriumi követése (FIBTEM, fibrinogénszint) alapján történik a célirányos pótlás [25]. Külön előnye, hogy adásakor nem kell thromboemboliás eseménnyel számolni.

A következő lépés a prokoaguláns faktorok pótlása PCC-készítménnyel. Adása az addigi kezelésre nem javuló vérzés alapján „vakon”, illetve a koagulációs tesztek (INR $\geq 1,5$, EXTEM-en megnyúlt CT) alapján válik indokolttá. A különböző készítmények eltérhetnek az egyes faktorok koncentrációjában, a FVII-tartalomban, illetve antikoagulációs aktivitásukban. Az előbbiek és a beadott mennyiség függvényében thromboemboliás szövődmény kialakulását idézhetik elő. A szokásos dózis $20 \mathrm{E} / \mathrm{ttkg}$.

A megfelelő, mindenre kiterjedő kezelés ellenére jelentkező gyöngyöző vérzés esetén 1250 NE FXIII adása 
jön szóba FC vagy krioprecipitátum formájában; FC-alapú alvadásellátás alkalmazása mellett erre nagyon ritkán kerül sor. Segít a döntésben, ha a vérszint 30\% alatti.

Továbbra sem rendeződő vérzés esetén - a TIC kialakulásában szerepet játszó valamennyi tényező rendezését követően, de nem elkésve - rFVIIa 'off-label' (indikáción túli) adása megkísérelhető 50-90g/ttkg dózisban, szükség szerint ismételve [26, 27].

Európában inkább a FC-alapú pótlást részesítik előnyben, a világos, logikus elgondolás előnyét azonban mindeddig csak egy egycentrumos prospektív randomizált tanulmány támasztja alá [28]. Az akut masszív vérzés, illetve koagulációs zavar ellátása többnyire empirikus kezeléssel kezdődik. Már ekkor is észszerúbbnek tűnik a FC-alapú módszer, de a FFP-alapú is elfogadható, különösen, ha az előbbi nem áll rendelkezésre. A későbbi, célirányos ellátás során is a differenciált kezelést lehetővé tevő FC-adás előnyösebb. Az ideális az lenne, ha empirikus kezelés egyáltalán nem történne, hanem kezdettől célirányos lenne a kezelés. Ennek feltétele a nagyon korai és gyors diagnosztika, ami VET-tel valósítható meg. Ugyanakkor már folynak próbálkozások az alvadási faktorok kórházi felvétel előtti pótlására, ami viszont a jelenlegi gyakorlatban csak empirikusan végezhető.

\section{Masszív transzfúziós protokoll és célirányos kezelés}

A fentiek figyelembevételével a traumacentrumokban ajánlott a helyi adottságokhoz, lehetőségekhez illesztett masszív vérzéses ellátási algoritmus - tágabb értelemben vett MTP - kidolgozása. Az empirikus, fix arányú kezelés legnagyobb hátránya, hogy az alvadási zavar részletei ismeretének hiányában az egyes összetevőkből elégtelen vagy felesleges mennyiség kerülhet beadásra. Ezért fontos a mielőbbi áttérés a GDCT-re. Az irányelvek megengedőek, az eddig leírt alapelvekre alapozva számos alternatívát - esetleg szekvenciában - ajánlanak: kezdetben többnyire empirikusan, akár fix arányban is, a továbbiakban célirányosan adandók a VVS-transzfúzió és az alvadási zavar kezelésére szolgáló vér- és/vagy faktorkészítmények (3. ábra).

A masszív traumás vérzés - különösen FC-alapú - ellátásának költségei magasak. Megfelelő indikáció esetén azonban a költségek megtérülnek [29]. A költségkímélés a legjobb ellátás elmaradását nem indokolhatja. Másrészről a hibás állapotfelmérés, esetleg túlzott félelem vagy defenzió által vezérelt, indokolatlan MTP-alkalmazás felesleges pénzköltés, amellett, hogy ártalmas is lehet. A helyes javallat felállításában segíthet az „agresszív” vérzés/véralvadás ellátást, a MTP-t aktiváló trigger meghatározása $[30,31]$. A vérzés súlyosságának becslésére, illetve a masszív transzfúzió szükségességének jóslására példa a TASH- (trauma-associated severe haemorrhage) score [32] (4. ábra), amely az interneten is könnyen hozzáférhető (például MDCalc).

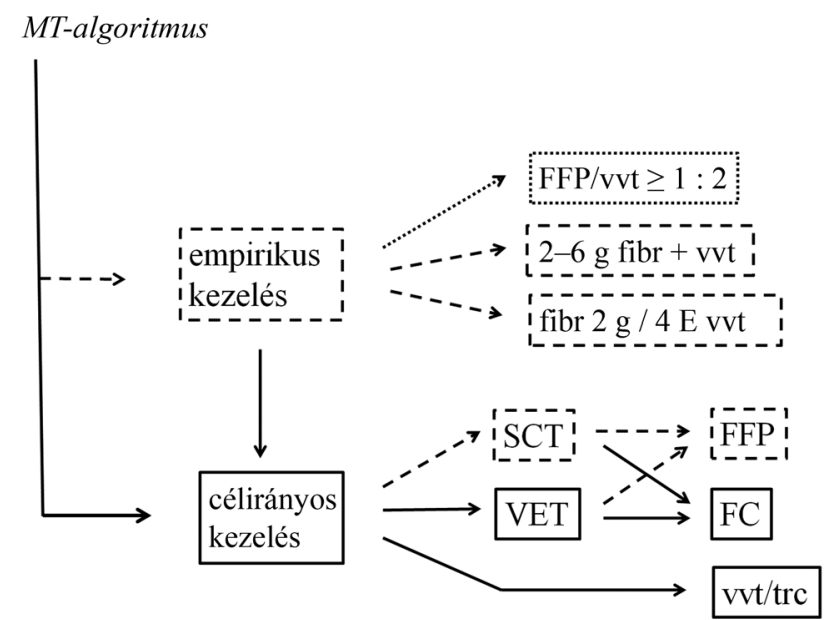

3. ábra

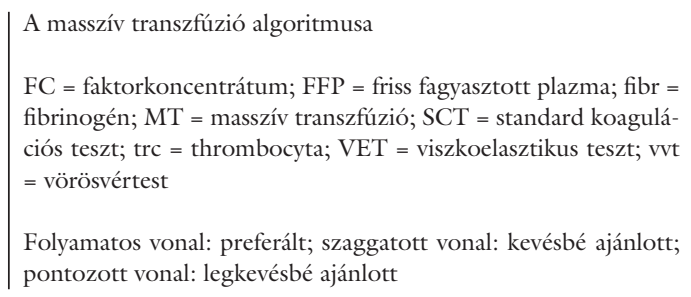

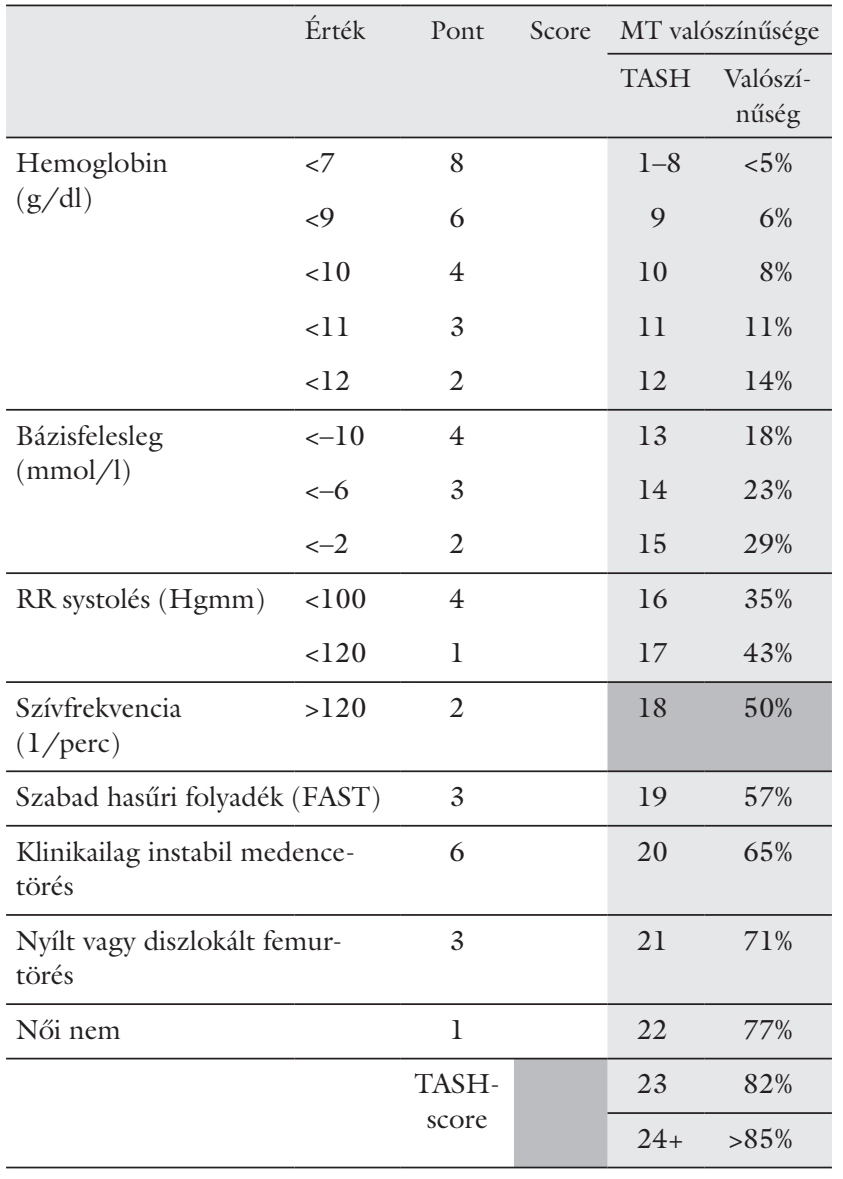

4. ábra A

FAST = célirányos traumatológiai ultrahangvizsgálat; $\mathrm{MT}=$ masszív transzfúzió; $\mathrm{RR}$ = vérnyomás; TASH = traumához kapcsolódó súlyos vérzés 


\section{A masszív transzfúziós protokoll és a vérgazdálkodási program kapcsolata}

A PBM-program a nem megfelelő vérzésellátás miatt szükségessé váló, nagyobb mennyiségú transzfúzió szövődményeinek megelőzését és a világszerte jelentkező allogén vérkészítményhiány enyhítését egyaránt célozza [33]. Pillérei: 1. a haemopoesis optimalizálása, 2. a vérzés és a vérhasználat minimalizálása, 3 . az anaemiatolerancia kihasználása és optimalizálása. Az akut trauma ellátása során csak a 2. és a 3. pillér elvei érvényesülhetnek. A traumás coagulopathia korszerü - gyakran preventív szemléletú kezelésének lényege, egyik célja és egyúttal eredménye a csökkent vérkészítmény-felhasználás. E tekintetben kiemelhető a faktoralapú pótlás és a megengedő hypotensio gyakorlata, a megszorító transzfúziós stratégia, a vértakarékos operatív technika, a vérmentő eljárások alkalmazása. Ezek mellett a kis méretû vércsövek használata, az oxigén kínálat/igény optimalizálása és az anaemiatolerancia elősegítése is segíti a programot. Egyelőre nem tisztázott a vas, illetve az eritropoetin szerepe az akut szituációban.

\section{Következtetések}

Az akut traumás vérzés ellátási gyakorlata az előző két évtizedben gyökeresen megváltozott. A célirányos, faktorkoncentrátum-alapú eljárás részesítendő előnyben. A morbiditási és letalitási haszon ismeretében a hazai gyakorlat is követi a változást, azonban még nem eléggé széles körben. A következő évek feladata az új koncepció eszközös és gyógyszeres feltételeinek megteremtése és a megkezdett képzés további szervezése, szélesítése. A korszerú véralvadás-ellátás segíthet a vérgazdálkodási program hazai elindításában és céljainak megvalósításában.

Anyagi támogatás: A közlemény megírása anyagi támogatásban nem részesült.

A szerző a cikk végleges változatát elolvasta és jóváhagyta.

Érdekeltségek: A szerzőnek nincsenek érdekeltségei.

\section{Irodalom}

[1] Kauvar DS, Lefering R, Wade CE. Impact of hemorrhage on trauma outcome: an overview of epidemiology, clinical presentations, and therapeutic considerations. J Trauma 2006; 60(6 Suppl): S3-S11.

[2] Chang R, Cardenas JC, Wade CE, et al. Advances in the understanding of trauma-induced coagulopathy. Blood 2016; 128: 1043-1049.

[3] Maegele M, Schöchl H, Cohen MJ. An update on the coagulopathy of trauma. Shock 2014; 41(Suppl 1): 21-25.

[4] MacLeod JB, Lynn M, McKenney MG, et al. Early coagulopathy predicts mortality in trauma. J Trauma 2003; $55: 39-44$.
[5] Maegele M, Lefering R, Yucel N, et al. Early coagulopathy in multiple injury: an analysis from the German Trauma Registry on 8724 patients. Injury 2007; 38: 298-304.

[6] Hagemo JS, Christiaans SC, Stanworth SJ, et al. Detection of acute traumatic coagulopathy and massive transfusion requirements by means of rotational thromboelastometry: an international prospective validation study. Crit Care 2015; 19: 97.

[7] Spahn DR, Bouillon B, Cerny V, et al. The European guideline on management of major bleeding and coagulopathy following trauma: fifth edition. Crit Care 2019; 23: 98.

[8] Morrison CA, Carrick MM, Norman MA, et al. Hypotensive resuscitation strategy reduces transfusion requirements and severe postoperative coagulopathy in trauma patients with hemorrhagic shock: preliminary results of a randomized controlled trial. J Trauma 2011; 70: 652-663.

[9] Babik B, Blaskó Gy, Fazakas J, et al. Management of life-threatening perioperative haemorrhages. [Az életveszélyes perioperatív vérzések ellátása. A Magyar Aneszteziológiai és Intenzív Terápiás Társaság szakmai irányelve, 2013.] Aneszteziol Int Ter. 2013; 43: 113-143.] [Hungarian]

[10] Gonzalez E, Moore EE, Moore HB, et al. Goal-directed hemostatic resuscitation of trauma-induced coagulopathy: a pragmatic randomized clinical trial comparing a viscoelastic assay to conventional coagulation assays. Ann Surg. 2016; 263: 1051-1059.

[11] Stensballe J, Henriksen HH, Johansson PI. Early haemorrhage control and management of trauma-induced coagulopathy: the importance of goal-directed therapy. Curr Opin Crit Care 2017; 23: $503-510$

[12] Giancarelli A, Birrer KL, Alban RF, et al. Hypocalcemia in trauma patients receiving massive transfusion. J Surg Res. 2016; 202: 182-187.

[13] Shakur H, Roberts I, Bautista R, et al. Effects of tranexamic acid on death, vascular occlusive events, and blood transfusion in trauma patients with significant haemorrhage (CRASH-2): a randomised, placebo-controlled trial. Lancet 2010; 376: 23-32.

[14] Wohlauer MV, Moore EE, Thomas S, et al. Early platelet dysfunction: an unrecognized role in the acute coagulopathy of trauma. J Am Coll Surg. 2012; 214: 739-746.

[15] Hagemo JS, Stanworth S, Juffermans NP, et al. Prevalence, predictors and outcome of hypofibrinogenaemia in trauma: a multicentre observational study. Crit Care 2014; 18: R52.

[16] Harr JN, Moore EE, Ghasabyan A, et al. Functional fibrinogen assay indicates that fibrinogen is critical in correcting abnormal clot strength following trauma. Shock 2013; 39: 45-49.

[17] Schlimp CJ, Voelckel W, Inaba K, et al. Estimation of plasma fibrinogen levels based on hemoglobin, base excess and Injury Severity Score upon emergency room admission. Crit Care 2013; 17: R137.

[18] Nakamura Y, Ishikura H, Kushimoto S, et al. Fibrinogen level on admission is a predictor for massive transfusion in patients with severe blunt trauma: analyses of a retrospective multicentre observational study. Injury 2017; 48: 674-679.

[19] McQuilten ZK, Wood EM, Bailey M, et al. Fibrinogen is an in dependent predictor of mortality in major trauma patients: a fiveyear statewide cohort study. Injury 2017; 48: 1074-1081

[20] Rourke C, Curry N, Khan S, et al. Fibrinogen levels during trauma hemorrhage, response to replacement therapy, and association with patient outcomes. J Thromb Haemost. 2012; 10: $1342-1351$.

[21] Watson GA, Sperry JL, Rosengart MR, et al. Fresh frozen plasma is independently associated with a higher risk of multiple organ failure and acute respiratory distress syndrome. J Trauma 2009; 67: $221-230$

[22] McQuilten ZK, Crighton G, Brunskill S, et al. Optimal dose, timing and ratio of blood products in massive transfusion: results from a systematic review. Transfus Med Rev. 2018; 32: 6-15.

[23] Holcomb JB, Tilley BC, Baraniuk S, et al. Transfusion of plasma, platelets, and red blood cells in a 1:1:1 vs a 1:1:2 ratio and mor- 
tality in patients with severe trauma: the PROPPR randomized clinical trial. JAMA 2015; 313: 471-482.

[24] Csomós Á, Gál J. Cost-effectiveness of goal-directed coagulation management in clinical practice. [A célorientált alvadásgátló kezelés költséghatékonysága a mindennapi transzfúziós gyakorlatban.] Aneszteziol Int Ter. 2013; 43: 152-156. [Hungarian]

[25] Schöchl H, Maegele M, Voelckel W. Fixed ratio versus goal-directed therapy in trauma. Curr Opin Anaesthesiol. 2016; 29: 234-244.

[26] Dutton RP, Parr M, Tortella BJ, et al. Recombinant activated factor VII safety in trauma patients: results from the CONTROL trial. J Trauma 2011; 71: 12-19.

[27] Hauser CJ, Boffard K, Dutton R, et al. Results of the CONTROL trial: efficacy and safety of recombinant activated factor VII in the management of refractory traumatic hemorrhage. J Trauma 2010; 69: 489-500

[28] Innerhofer P, Fries D, Mittermayr M, et al. Reversal of traumainduced coagulopathy using first-line coagulation factor concentrates or fresh frozen plasma (RETIC): a single-centre, parallelgroup, open-label, randomised trial. Lancet Haematol. 2017; 4: e258-e271. [Correction: Lancet Haematol. 2017; 4: e257.]
[29] Nardi G, Agostini V, Rondinelli B, et al. Trauma-induced coagulopathy: impact of the early coagulation support protocol on blood product consumption, mortality and costs. Crit Care 2015; 19: 83.

[30] Ogura T, Lefor AK, Masuda M, et al. Modified traumatic bleeding severity score: early determination of the need for massive transfusion. Am J Emerg Med. 2016; 34: 1097-1101.

[31] Cantle PM, Cotton BA. Prediction of massive transfusion in trauma. Crit Care Clin. 2017; 33: 71-84.

[32] Maegele M, Lefering R, Wafaisade A, et al. Revalidation and update of the TASH-score: a scoring system to predict the probability for massive transfusion as a surrogate for life-threatening haemorrhage after severe injury. Vox Sang. 2011; 100: 231-238.

[33] Babik B, Fazakas J, Matusovits A, et al. Forced steps for making improvements in severe perioperative haemorrhage. [Lépéskényszerben - új feladatok az életveszélyes perioperatív vérzések ellátásában.] Orv Hetil. 2019; 160: 203-213. [Hungarian]

(Szentkereszty Zoltán dr., Debrecen, Bartók Béla út 2-26., 4032 e-mail: drzsz@freemail.hu)

\section{"Tuti sunt omnes unus ubi defenditur." (Ahol egy oltalmat nyer, mindenki biztonságban van.)}

A cikk a Creative Commons Attribution 4.0 International License (https://creativecommons.org/licenses/by/4.0/) feltételei szerint publikált Open Access közlemény, melynek szellemében a cikk bármilyen médiumban szabadon felhasználható, megosztható és újraközölhetö, feltéve, hogy az eredeti szerző és a közlés helye, illetve a CC License linkje és az esetlegesen végrehajtott módosítások feltüntetésre kerülnek. (SID_1) 